\title{
Measurement of the dimensions of personality traits in patients addicted to psychoactive substances in context of relapses
}

\author{
Krzysztof Chmielowiec ${ }^{1}$ ABCDEF, https://orcid.org/0000-0003-4254-5466, \\ Agnieszka Boroń ${ }^{2}$ ABCDEF, https://orcid.org/0000-0003-3574-5726
}

\begin{abstract}
${ }^{1}$ Department of Hygiene and Epidemiology, Collegium Medicum, University of Zielona Góra, Poland ${ }^{2}$ Department of Clinical and Molecular Biochemistry, Pomeranian Medical University, Szczecin, Poland
\end{abstract}

\begin{abstract}
Introduction: Recurrent use of psychoactive substances, including alcohol, affects most patients. It is an expression of the chronicity of the disease process. Understanding the causes of this phenomenon is the key to searching for effective therapeutic strategies for this disease.

The aim: Analysis of individual dimensions of personality traits in patients in the context of relapses.

Material and method: The research was carried out on a group of 301 people addicted to psychoactive substances staying in an addiction therapy center in Lubuskie and Zachodniopomorskie voivodships in Poland. The subjects were divided into two groups. The first group consisted of addicts with reported one-time therapy. The second group consisted of addicts who received at least two treatments at an addiction therapy center. The personality dimension was measured using the NEO-FFI questionnaire and the STAI questionnaire.

Results: The following percentages of neuroticism (NF NEUR) were marked in people addicted to psychoactive substances with a single stay in an inpatient treatment center: $8.55 \%$ with low intensity, $40.13 \%$ with moderate intensity and $51.32 \%$ with high intensity. On the other hand, in people addicted to psychoactive substances with multiple stays in an inpatient treatment center, the features of low-grade neuroticism were found to be $6.85 \%, 25.34 \%$ of moderate and $67.81 \%$ of high intensity $(\chi 2=8.643$, $p$ $=0.013$ ).

Conclusions: A higher score on the Nervousness Scale of the Neo FFI inventory has a significant impact on the course of addiction and the occurrence of relapses.
\end{abstract}

Keywords: relapses of addiction, NEO-FFI questionnaire, STAI questionnaire

\section{Streszczenie}

Wprowadzenie: Powtarzające się używanie substancji psychoaktywnych, w tym alkoholu, dotyka większość pacjentów. Jest wyrazem przewlekłości procesu chorobowego. Zrozumienie przyczyn tego zjawiska jest kluczem do poszukiwania skutecznych strategii terapeutycznych dla tej choroby.

Cel: Analiza poszczególnych wymiarów cech osobowości pacjentów w kontekście nawrotów.

Materiał i metody: Badania przeprowadzono na grupie 301 osób uzależnionych od środków psychoaktywnych przebywających w ośrodku terapii uzależnień w województwach lubuskim i zachodniopomorskim w Polsce. Pacjentów podzielono na dwie grupy. Pierwsza grupa składała się z osób uzależnionych, dla których przeprowadzono jednorazową terapię. Druga grupa składała się z osób uzależnionych, które otrzymały co najmniej dwa zabiegi w ośrodku terapii uzależnień. Wymiar osobowości mierzono za pomocą kwestionariusza NEO-FFI oraz kwestionariusza STAI.

Wyniki: Wśród osób uzależnionych od środków psychoaktywnych z jednorazowym pobytem w ośrodku lecznictwa stacjonarnego zaobserwowano następujące odsetki neurotyzmu (NF NEUR): 8,55\% o niskiej intensywności, 40,13\% o umiarkowanej intensywności i 51,32\% o dużej intensywności. Z kolei u osób uzależnionych od środków psychoaktywnych z kilkoma pobytami w szpitalnym ośrodku leczniczym stwierdzono cechy neurotyzmu niskiego stopnia 6,85\%, 25,34\% umiarkowanego i 67,81\% wysokiego ( $\chi 2=8,643$, p. =0,013).

Wnioski: Wyższy wynik w Skali Nerwowości inwentarza Neo FFI ma istotny wpływ na przebieg uzależnienia i występowanie nawrotów. 
Słowa kluczowe: nawroty uzależnienia, kwestionariusz NEO-FFI, kwestionariusz STAI

\section{Introduction}

Recurrent use of psychoactive substances, including alcohol, affects most patients. It is an expression of the chronicity of the disease process and despite numerous models and methods of psychotherapeutic or community treatment [1], the effectiveness of these techniques is unsatisfactory and the course of the disease is characterized by relapses affecting the vast majority of patients [2]. Understanding the causes of this phenomenon is the key to searching for effective therapeutic strategies for this disease, affecting not only the patients themselves but also their families [3].

Addictions, especially drug addictions, are characterized by a very high recurrence rate (even over $90 \%$ per year). Therefore, it seems important to find the reasons for such a high scale of treatment failures. One of them in terms of endogenous causes may be genetic susceptibility, especially in terms of the most important in the mechanism of addiction - dopaminergic system receptors.

The simplest definition of relapse can be described as the re-use of a substance after a period of abstinence. There are various theoretical approaches as to whether we can talk about relapse in the case of a single incident or only repeated one, depending on the intensity of the use of a psychoactive substance. In different authors $[4,5,6]$ we can distinguish, depending on the prism of the methodological concept of the relapse process, with slowly progressing phases, episodic use (lapse), systematic, intensive use as before the last period of abstinence (relapse), systematic but limited use, and finally understanding relapse as the need to start another treatment as a result of the current abstinence violation [7].

The distinction between episodic use (lapse) and systematic use, similarly to the current period of abstinence, is noticed by Marlat [8], who defined relapse as a failure of a pro-health behavior change strategy, the effect of which was to be sober. In their psychological concept of relapse, the essence of relapse prevention is the effectiveness of self-efficacy in stressful situations, sometimes behaviorally enhanced by their actual effectiveness in the face of encountered difficulties. Episodic use (lapse) in such a situation is a negative reinforcement, contradicting self-efficiency.

According to this concept, the risk of relapse is influenced by the internal factors of the individual, such as: inability to cope, unfavorable self-esteem and positive emotions related to the substance when it is difficult to postpone gratification, and external factors related to the influence of the environment, such as its pressure, tensions or situations that cause strong emotions, regardless of vector.

Litman describes a model of relapse in the interaction between the person and the situation, where the relapse is the result of failure of defense mechanisms to a given risk situation [9]. Risk-stimulating situations involve anxiety and depressive states, including social phobia, the positive role assigned to a substance by the patient, and various forms of downplaying episodic consumption of the substance. The strength of the belief about the reasons for breaking abstinence and the reasons for which it is currently preserved, as well as the knowledge of the previous causes and steps or stages leading to breaking abstinence, generally composed of minor but inevitably leading to relapse behavior and decisions, determine the prevention and consolidation of abstinence [10]. An addicted person can actively influence every part of this process. This is also confirmed by long-term studies of opiate addicts, where active measures preventing the return to active opioid use are the basis of many years of therapeutic success [11]. The author of the quoted publication, Vaillant, defines the factors emphasizing the strength and source (external or internal) of the obtained long-term abstinence as dependent on social control, changing the addictive substance into another, support in self-development groups and strong stimuli from newly created emotional relationships [11]. Similarly, the greater effectiveness of action-based therapy, testing in practice individual cognitive concepts of maintaining sobriety and own competences in this area, is emphasized by the authors who rely on cognitive-behavioral treatment models [6]. Long-term sobriety is favored by the process of therapeutic analysis of the cause of the last abstinence break, realizing the consequences in the form of losses exceeding the gains from using the substance [7].

Sanchez-Craig draws attention to the importance of the cognitive schema of negative assessment of one's own abilities increasing the risk of relapse [12].

Rollnick et al., based on Bandura's theory, indicate an important corrective and supportive role of the social environment - apart from the possibilities and expected effectiveness of own defense schemes - in estimating the risk of recurrence [13].

The initial psychobiological concept is the theory of hunger and insufficient control [14]. It is based on the assumptions of arousing hunger (called craving) after the first use of the substance, leading to its further uncontrolled consumption. Even a small amount of the substance causes the addict's inability to refrain from subsequent doses. The feeling of hunger for a substance 
is caused not only by its presence in the body, but also by emotional stimuli, memory traces or the sight of the substance, and it means a state that is supposed to soothe the consumption of a psychoactive substance. It was denied in an experiment $[14,15]$ where administration of small doses of alcohol did not cause thrust.

It is worth considering the neurobiological determinants of addictions in terms of the processes and involvement of individual parts of the brain (functions of the brain), at a more detailed level of neurotransmission systems (such as serotonergic and dopaminergic) and finally genetic predispositions determining the functioning of these systems in addicts [16]. In the functional scope, a very important role in the development of addiction is played by the reward system with the most important role of dopamine in it [17].

\section{The aim}

Analysis of individual dimensions of personality traits in patients in the context of relapses.

\section{Material and methods}

\section{Study group}

Patients in the study group were recruited in the inpatient drug addiction treatment centers in the Lubuskie and Zachodniopomorskie voivodships. The number of 153 people had the first-time stay, while for 148 people it was another stay in a treatment and therapy center. The respondents gave their voluntary, written consent to participate in the study. Patients recruited in treatment and therapy centers remained in a state of abstinence for not less than three months to minimize the impact of addictive substances on the results of psychometric tests. The consent of the Bioethics Committee of the Pomeranian Medical University in Szczecin was obtained (KB-0012/106/16).

It was noted that the average age of people addicted to psychoactive substances with a single stay in an inpatient treatment center was about 27 years (SD = 6.22), while the age range for the minimum values was 18 years and for the maximum value 47 years. Similarly, the average age of people addicted to psychoactive substances with multiple stays in an inpatient treatment center was about 29 years $(\mathrm{SD}=6.58)$, while the age range for the minimum values was 17 years and for the maximum value was 57 years (Table 1). Due to the adopted division, taking into account the amount of therapy in an inpatient center, basic statistics are presented for people addicted to psychoactive substances who have multiple stays in an inpatient therapy center. The mean number of in-patient treatments for these people was 3.68 stays ( $S D=2.80$ ) and the range of in-patient treatments was 2 stays for the minimum values and 23 stays for the maximum value (Table 1.).

\section{Measuring the dimensions of personality traits}

Personality traits were measured with the use of STAI Questionnaire - State and Trait Anxiety Inventory

Table 1. Statistical characteristics of age in the study and control groups and the amount of therapy in an in-patient center in the study

\begin{tabular}{|c|c|c|c|}
\hline & & \multicolumn{2}{|c|}{ Study group $(n=301)$} \\
\hline & & One-off stay $(n=153)$ & $\begin{array}{l}\text { Relapses in therapy } \\
\qquad(n=148)\end{array}$ \\
\hline \multirow{2}{*}{ Age } & mean/SD & $27.4(\mathrm{SD}=6.2)$ & $28.97(\mathrm{SD}=6.6)$ \\
\hline & $\operatorname{Min} / \operatorname{Max}$ & $18-47$ & $17-57$ \\
\hline \multirow{2}{*}{$\begin{array}{l}\text { Number of therapies in } \\
\text { an inpatient facility }\end{array}$} & mean/SD & $1(0.0)$ & $3,78(\mathrm{SD}=2.8)$ \\
\hline & $\operatorname{Min} / \operatorname{Max}$ & $1-1$ & $2-23$ \\
\hline
\end{tabular}

NEO-FFI Questionnaire - Personality Inventory. The respondent is assessed in the oven with dimensions such as: neuroticism, extraversion, openness (to experience), conscientiousness and agreeableness.

\section{Statistical analysis}

The statistical analysis used the STATISTICA 13 package. For measurable features in people addicted to psychoactive substances, who have a single and multiple stay in an inpatient treatment center (number of therapy in an inpatient center, number of years of illness, onset of addiction, age), and for the age of the following descriptive statistics were given in the control sample: minimum and maximum values, arithmetic mean and standard deviation. On the other hand, for non-measurable, i.e. frequency (qualitative) traits in people addicted to psychoactive substances who have a single and multiple stay in an inpatient treatment center (relapse in addiction, marital status, education), the numbers in the given groups and the percentages in the groups were given.

The analysis using the Chi2 ( $\chi 2)$ test was taken into account in the differences in the frequency of the anxiety sten norm factor, the sten norms of the NEO-FFI questionnaire for the neuroticism trait, the extraversion 
trait, the openness trait, and the characteristics of agreeableness and conscientiousness as well as the sten norms for the ADHD scale. In the cases of using the Chi2 test, $\mathrm{p} \leq 0.05$ were considered significant statistical differences.

\section{Results}

Comparing people addicted to psychoactive substances with a single stay in an inpatient therapy center with people addicted to psychoactive substances with multiple stays in an inpatient therapy center, significant statistical differences in the frequency of stent norms of the neurotic character of the NEO-FFI (NF NEUR) questionnaire were found (Table 2.).

The following percentages of neuroticism (NF
NEUR) were marked in people addicted to psychoactive substances with a single stay in an inpatient treatment center: $8.55 \%$ with low intensity, $40.13 \%$ with moderate intensity and $51.32 \%$ with high intensity. On the other hand, in people addicted to psychoactive substances with multiple stays in an inpatient treatment center, the features of low-grade neuroticism were shown to be $6.85 \%, 25.34 \%$ of medium intensity and $67.81 \%$ of high intensity ( $\chi 2=8.643, \mathrm{p}=0.013$ ) (Table 2.).

\section{Discussion}

In our research, male patients were taken into account. This was explained by a completely different course of addiction in both sexes. As far as relapse of addiction is concerned, the literature also analyzed in this

Table 1.Comparison of personality traits (sten norms) of the group of people with one-time therapy and those with relapses in therapy.

\begin{tabular}{|c|c|c|c|c|c|}
\hline & & & & \multicolumn{2}{|c|}{ Test $\chi 2$} \\
\hline & & $\begin{array}{l}\text { therapy } \\
(\mathrm{N}=153)\end{array}$ & $\begin{array}{c}\text { therapy } \\
(\mathrm{N}=148)\end{array}$ & $\chi^{2}$ & $\mathrm{p}$ \\
\hline \multirow{3}{*}{ STAI ST Sten } & short & $34(22.5 \%)$ & $25(17.1 \%)$ & \multirow{3}{*}{3.325} & \multirow{3}{*}{0.190} \\
\hline & medium & $55(36.4 \%)$ & $46(31.5 \%)$ & & \\
\hline & high & $62(41.1 \%)$ & $75(51.4 \%)$ & & \\
\hline \multirow{3}{*}{ STAI C Sten } & short & $9(6 \%)$ & $8(5.5 \%)$ & \multirow{3}{*}{3.132} & \multirow{3}{*}{0.209} \\
\hline & medium & $59(39 \%)$ & $43(29.7 \%)$ & & \\
\hline & high & $83(55 \%)$ & $94(64.8 \%)$ & & \\
\hline \multirow{3}{*}{ NF NEUR Sten } & short & $13(8.6 \%)$ & $10(6.8 \%)$ & \multirow{3}{*}{8.643} & \multirow{3}{*}{$0.013^{*}$} \\
\hline & medium & $61(40.1 \%)$ & 37 (25.3\%) & & \\
\hline & high & $78(51.3 \%)$ & $99(67.8 \%)$ & & \\
\hline \multirow{3}{*}{ NF EKSTR Sten } & short & $20(13.2 \%)$ & $21(14.4 \%)$ & \multirow{3}{*}{0.156} & \multirow{3}{*}{0.927} \\
\hline & medium & $73(48 \%)$ & $71(48.6 \%)$ & & \\
\hline & high & $59(38.8 \%)$ & $54(37 \%)$ & & \\
\hline \multirow{3}{*}{ NF OTW Sten } & short & $46(30.3 \%)$ & $33(22.6 \%)$ & \multirow{3}{*}{5.541} & \multirow{3}{*}{0.063} \\
\hline & medium & $77(50.7 \%)$ & $69(47.3 \%)$ & & \\
\hline & high & $29(19 \%)$ & $44(30.1 \%)$ & & \\
\hline \multirow{3}{*}{ NF UGOD Sten } & short & $49(32.2 \%)$ & $58(39.7 \%)$ & \multirow{3}{*}{4.127} & \multirow{3}{*}{0.127} \\
\hline & medium & $76(50 \%)$ & $73(50 \%)$ & & \\
\hline & high & $27(17.8 \%)$ & $15(10.3 \%)$ & & \\
\hline \multirow{3}{*}{ NF SUM Sten } & short & $28(18.4 \%)$ & $29(19.9 \%)$ & \multirow{3}{*}{2.546} & \multirow{3}{*}{0.280} \\
\hline & medium & $65(42.8 \%)$ & $73(50 \%)$ & & \\
\hline & high & $59(38.8 \%)$ & $44(30.1 \%)$ & & \\
\hline
\end{tabular}

*Statistically significant differences 
regard. In numerous studies, no differences in terms of gender of patients were found $[18,19]$. Some observations showed slightly better results of alcohol addiction therapy in women [20], and some indicated a higher risk of relapse in this group [21,22] than in men: $73 \%$ versus $46 \%$ [23]. The Jarvis study [24] should be cited here, and the metaanalysis of gender significance for the results of addiction therapy emphasizes that the female gender has a better prognosis than the male one in terms of maintaining abstinence for up to 12 months after the end of treatment. In longer follow-up, men achieved significantly lower rates of relapse compared to women. In one study, female sex turned out to be by far the strongest predictor of relapse into alcohol drinking during the 36-month follow-up period [23].

There are many reports on the question of the role of personality and its dimensions and traits in relapses $[25,26]$. Tarnai and Young [27] showed that the dimension of introversion, measured with the Strong and Campbell Inventory, was associated with a significant risk of breaking abstinence. As in the authors' own research, many studies took into account the five-factor model of personality, which defines five domains representing an extensive personality taxonomy: neuroticism, extraversion, openness, conscientiousness and agreeableness [28]. Studies have shown that interpersonal conflicts may be an important predictor of the risk of relapse in addicts [29]. The lower the degree of agreeableness (and thus the greater the tendency to so-called interpersonal conflicts), the higher the risk of relapse. Fisher et al. [28] proved that among the domains, neuroticism and conscientiousness (consisting of organization, motivation, and persistence) have a significant impact on the likelihood of relapse. On the other hand, the maximum risk of recurrence concerns patients who are characterized by low conscientiousness and a high level of neuroticism in the NEO-PI-R inventory $[23,28]$. Less conscientiousness is associated with the lack of organizational skills and the necessary motivation to plan behavior in risky situations.

In own research, the following percentages of neuroticism (NF NEUR) were marked in people addicted to psychoactive substances with a single stay in an inpatient treatment center: $8.55 \%$ with low intensity, $40.13 \%$ with moderate intensity and $51.32 \%$ with high intensity. On the other hand, in people addicted to psychoactive substances with multiple stays in an inpatient treatment center, the features of low-grade neuroticism were shown to be $6.85 \%, 25.34 \%$ of medium intensity and $67.81 \%$ of high intensity $(\chi 2=8.643, p=0.013)$.

Researchers attach great importance to the characteristic personality trait associated with the search for stimulation and novelty, the so-called amendments seeking in the context of an increased risk of recurrence
[30,31], and harm avoidance, which include the need to constantly find new stimuli, extravagance, impulsiveness, unbridled optimism, and mess. All these features favor the development of addiction and the risk of relapse after a period of abstinence [30].

Longer periods of abstinence have been noted in people who do not show any rebellious, impulsive features or those that may lead to social alienation. Researchers also emphasize the importance of impulsivity perceived as a multidimensional construct, prompting the patient to react quickly, unplanned to internal and external stimuli, without reflecting on the effect of such behavior [32]. In patients who are prone to relapse, we observe affect disorders, antisocial features and impulsiveness. Miller [33] argues that the elevated characteristics of abstainers are reflective, non-impulsive, and targeted cognitive behavior.

In the context of own research, it should be emphasized that other neuropsychological factors also play a role, which are associated with weaker therapy outcomes and correlate with a greater tendency to relapse into addiction. These include excessive narrowing of attention processes [34] and significant cognitive deficits [35]. It is them that may limit the possibilities of using the therapeutic program and modify the activation of coping mechanisms in difficult and stressful situations, and thus affect the maintenance of abstinence. The intellectual level of the patient is also important in predicting the risk of recurrence - a lower IQ value and a reduced verbal scale of the text were observed in relapses [36].

Impulsivity is an important aspect of personality and has its reference to the biological basis, which is related to the dysfunction of the central nervous system - mostly in the frontal lobe and the left hemisphere of the brain [37]. A relationship has also been demonstrated with the function of the serotonergic system (decreased) [38, 39].

\section{Conclusions}

The analysis of individual personality dimensions and other examined psychopathological traits in patients in the context of relapses turned out to be justified and showed a number of statistically significant differences. It should be concluded that the higher score of the Neo FFI Inventory Nervousness Scale has a significant impact on the course of addiction and the occurrence of relapses.

\section{Conflict of interest}

The authors have declared no conflict of interest.

\section{References:}

1. Conroy D., Brower K.J., Marshall J., Crawford M. Psychological treatments of alcohol use disorders. W: P. Tyrer i K. R. Silk (red.), Effective treatments in psychiatry. Cambridge, UK: Cambridge 
University Press,2008:265-287.

2. McLellan A.T., Lewis D.C., O’Brien C.P. Kleber, H.D. Drug dependence, a chronic medical illness: implications for treatment, insurance, and outcomes evaluation. Journal of American Medical Association - JAMA, 2000: 284, 1689-1695.

3. Litman, G., Eiser, J., Rawson, N. Oppenheim, A. Towards a typology of relapse: A preliminary report. Drug and Alcohol Dependence,1977: 2, 157-162.

4. Dimeff L.A., Marlatt G.A. Relapse prevention. W: Hester RK (red.) Handbook of alcoholism treatment approaches. Boston: Allyn and Bacon,1995: 176-194.

5. Saunders B., Allsop S. Relapse; a critique. Gossop M (red) Relapse and Addictive Behavior, London: Routledge,1989: 249-277.

6. Saunders, B, . Allsop, S. Nawroty - polemika. W: M. Gossop (red.), Nawroty w uzależnieniach. Warszawa: Państwowa Agencja Rozwiązywania Problemow Alkoholowych, 1997: 205-225.

7. Wojnar M., Ślusarska A. Jakubczyk A. Nawroty w uzależnieniu od alkoholu. Część 1: Definicje i modele. Alkoholizm i Narkomania, 2006: 19 (4), 379-395.

8. Marlat G.A., Gordon J.R. Determinants of relapse: implications of maintenance of behavior change, w: Davidson PO, Davidson SM (red) Behavioral medicine: Changing health lifestyle, New York: Brunner/Mazel, 1980, 410-452.

9. Litman G.K. Alkoholism survival: the prevention of relapse. W; Miller WR, Heather N (red)Treating Addictive Behaviors, New York: Plenum Press, 1986: 391-405.

10. Marlatt, A. G., Gordon R.J. Zapobieganie nawrotom - kierunki rozwoju. W: M. Gossop (red.), Nawroty w uzależnieniach. Warszawa: Państwowa Agencja Rozwiązywania Problemów Alkoholowych, 1997: 226-237.

11. Romaniuk R. Nawroty objawów choroby. Terapia Uzależnienia i Współuzależnienia, 2009: 5, 16-20.

12. Sanchez-Craig M. Cognitive and behavioral coping strategies in the reappraisal of stressfull social situations. Journal of Counseling Psychology,1976: 23, 7-12.

13. Rollnick S., Heather N. The application of Bandura's self-efficacy theory to abstinence-oriented alcoholism treatment. Addictive Behaviors,1982: 7 (3), 243-250.

14. Ludwig A.M., Winkler A. "Craving” and relapse to drink. Qarterly Journal of Studies on Akohol,1974: 35 (1 pt A), 108-130.

15. Polich J.M., Armor D.J., Braiker H.B. Patterns of alcoholism over four years. Journal of Studies odf Alcohol, 1980: 41 (5), 397-416.

16. Wojnar M., Brower K.J. Neurobiologiczne mechanizmy uzależnienia. W: P Jabłoński, B Bukowska, C. Czabała (red.) Uzależnienie od narkotyków Podręcznik dla terapeutów, KBPiN 2012.

17. Kostkowski W. Dopamina a mechanizm nagrody i rozwój uzależnień; fakty i hipotezy, Alkoholizm i Narkomania , 2000: 13, 2, (55), 189-212.

18. Schneider K.M., Kviz F.J., Isola M.L., Filstead W.J. Evaluating multiple outcomes and gender differences in alcoholism treatment. Addictive Behaviors, 1995: 20, 1-21.

19. Moos R.H., Moos B.S. Long-term influence of duration and intensity of treatment on previously untreated individuals with alcohol use disorders. Addiction,2003: 98, 325-337.

20. McKay J.R., Lynch K.G., Pettinati H.M., Shepard D.S. An examination of potential sex and race effects in a study of continuing care for alcohol- and cocaine-dependent patients. Alcoholism: Clinical and Experimental Research, 2003: 27, 13211323.

21. Rubin A., Stout R.L., Longabaugh R. Gender differences in relapse situations. Addiction, Supplement,1996: S111-120.

22. Walton M.A., Blow F.C., Bingham C.R., Chermack S.T. Individual and social/environmental predictors of alcohol and drug use 2 years following substance abuse treatment. Addictive Behaviors, 2003: 28, 627-642.

23. Bottlender M., Soyka M. Impact of different personality dimensions (NEO Five-Factor Inventory) on the outcome of alcohol-dependent patients 6 and 12 months after treatment. Psychiatry Research, 2005: 136, 61-67.

24. Jarvis T.J. Implications of gender for alcohol treatment research: a quantitative and qualitative review. British Journal of Addiction, 1992: 87, 1249-1261.

25. Janowsky D.S., Boone A., Morter S., Howe L. Personality and alcohol/substance-use disorder patient relapse and attendance at self-help group meetings. Alcohol and Alcoholism,1999: 34, 359-369.

26. Janowsky D.S., Fawcett J., Meszaros K., Verheul R. Core heritable personality characteristics and relapse in alcoholics. Alcoholism: Clinical and Experimental Research, 2001: 25, 94S-98S.

27. Tarnai J., Young F.A. Alcoholics. personalities: extravert or introvert? Psychological Reports,1983: 53, 123-127.

28. Fisher L.A., Elias J.W, Ritz K. Predicting relapse to substance abuse as a function of personality dimensions. Alcoholism: Clinical and Experimental Research, 1998: 22, 1041-1047.

29. Saunders B., Allsop S. Relapse: a psychological perspective. British Journal of Addiction, 1987: 82, 417-429

30. Willinger U., Lenzinger E., Hornik K., Fischer G., Schonbeck G., Aschauer H.N., Meszaros K. Anxiety as a predictor of relapse in detoxified alcohol-dependent patients. Alcohol and Alcoholism, 2002: 37, 609-612.

31. Kravitz H.M., Fawcett J., McGuire M., Kravitz G.S., Whitney M. Treatment attrition among alcohol-dependent men: is it related to novelty seeking personality traits? Journal of Clinical Psychopharmacology, 1999: 19, 51-56.

32. Moeller F.G., Barratt E.S., Dougherty D.M., Schmitz J.M., Swann A.C. Psychiatric aspects of impulsivity. American Journal of Psychiatry, 2001: 158, 1783-1793.

33. Miller W.R., Westerberg V.S., Harris R.J., Tonigan J.S. What predicts relapse? Prospective testing of antecedent models. Addiction, 1996: 91 Supplement, S 155-172.

34. Cox W.M., Hogan L.M., Kristian M.R., Race J.H. Alcohol attentional bias as a predictor of alcohol abusers. treatment outcome. Drug and Alcohol Dependence,2 002: 68, 237-243.

35. Tapert SF, Ozyurt SS, Myers MG, Brown SA. Neurocognitive ability in adults coping with alcohol and drug relapse temptations. American Journal of Drug and Alcohol Abuse, 2004: 30, 445-460.

36. Wehr A., Bauer L.O. Verbal ability predicts abstinence from drugs and alcohol in a residential treatment population. Psychological Reports, 1999: 84, 1354-1360.

37. Bottlender M., Soyka M. Impact of different personality dimensions (NEO Five-Factor Inventory) on the outcome of alcohol-dependent patients 6 and 12 months after treatment. Psychiatry Research, 2005: 136, 61-67.

38. Lesch K.P., Merschdorf U. Impulsivity, aggression, and serotonin: a molecular psychobiological perspective. Behavioral Sciences and the Law, 2000: 18, 581-604.

39. Heinz A., Mann K., Weinberger D.R., Goldman D. Serotonergic dysfunction, negative mood states, and response to alcohol. Alcoholism: Clinical and Experimental Research, 2001: 25, 487495. 


\section{Corresponding author}

Dr Krzysztof Chmielowiec

Department of Hygiene and Epidemiology

Collegium Medicum, University of Zielona Góra,

Zyty 28 St., 65-046 Zielona Góra, Poland

e-mail: k.chmielowiec@wlnz.uz.zgora.pl

Otrzymano:08.01.2021

Zrecenzowano:29.01.2021

Przyjęto do druku: 19.02.2021 